\title{
EMbatTled River
}





\title{
EMBATTLED RiveR
}

\section{The Hudson and Modern American}

Environmentalism

\author{
DAVID SCHUYLER
}

Cornell University Press

ITHACA AND LONDON 
Copyright @ 2018 by Cornell University

All rights reserved. Except for brief quotations in a review, this book, or parts thereof, must not be reproduced in any form without permission in writing from the publisher. For information, address Cornell University Press, Sage House, 512 East State Street, Ithaca, New York 14850. Visit our website at cornellpress.cornell.edu.

First published 2018 by Cornell University Press

Printed in the United States of America

Library of Congress Cataloging-in-Publication Data

Names: Schuyler, David, author.

Title: Embattled river : the Hudson and modern American environmentalism / David Schuyler.

Description: Ithaca : Cornell University Press, 2018. I Includes bibliographical references and index.

Identifiers: LCCN 2017051164 (print) | LCCN 2017053547 (ebook) | ISBN 9781501718069 (epub/mobi) | ISBN 9781501718076 (pdf) | ISBN 9781501718052 I ISBN 9781501718052 (cloth; alk. paper)

Subjects: LCSH: Environmentalism-Hudson River Valley (N.Y. and N.J.)-History. I Environmental protection-Hudson River Valley (N.Y. and N.J.) I Hudson River Valley (N.Y. and N.J.)Environmental conditions.

Classification: LCC GE198.H83 (ebook) I LCC GE198.H83 S34 2018

(print) I DDC 333.91/4097473-dc23

LC record available at https://lccn.loc.gov/2017051164 
For Kenneth T. Jackson 
